\title{
TRAVEL MOTIVATIONS OF TOURISTS VISITING Kruger National Park
}

\author{
PEET VAN DER MERWE \\ MELVILLE SAAYMAN \\ Institute for Tourism and Leisure Studies \\ North-West University \\ South Africa \\ Correspondence to: Peet van der Merwe \\ e-mail: peet.vandermerwe@nwu.ac.za \\ Postal Address: Private Bag X6001, North-West University, Potchefstroom 2520, South Africa
}

\begin{abstract}
The Kruger National Park (KNP) one of the largest conservation areas in South Africa, attracts in excess of one million visitors a year and is regarded as an icon destination in international tourism. Since this park attracts more tourists than any other park in South Africa, the purpose of this article is to determine the reasons (the travel motives) why tourists visit the park. Little research has been done on travel motives to national parks and this was the first of its kind in South Africa. The research was conducted by means of questionnaires. A factor analysis was used to determine the travel motives. Six factors were identified, namely nature, activities, attractions, nostalgia, novelty and escape from routine. Some of these motives were confirmed by similar research in other countries, although the similarities are not significant. This research confirmed that different attractions and destinations fed different travel motives, hence the need for more studies of this nature to be conducted.
\end{abstract}

Keywords: Travel motives, Ecotourism, Wildlife tourism, National Parks, destinations.

The Kruger National Park (KNP) was formally established in 1926, with the amalgamation of the Sabi and the Singwitsi Game Reserves. The reason behind the conception of the park was to stop uncontrolled hunting in this area. Therefore, the main purpose was that of conservation. However, at the time of the proclamation of the Kruger National Park in 1926, the idea of tourism was already well established (Joubert 2007; Pienaar 2007). Since then, tourism has developed and currently the park attracts in excess of one million tourists or visitors per year. It is one of the top five international tourist destinations in South Africa. Even though the park is a top international attraction, most tourists (approximately $80 \%$ ) are local tourists. This confirms that the park has successfully completed the transition from a pure conservation area to a tourist attraction of international significance that both benefits tourism and makes a contribution to the local community and its economy. In highlighting the importance of national parks, Uysal, McDonald and Martin (1994) state that national parks and natural areas are powerful magnets to tourists, and that these attractions are major export earners. In support of the latter, Saayman and Saayman (2006) found that the Kruger National Park (Figure 1) generated approximately R1,5 billion for the region annually. Eagles and McCool (2002) stated that the Kruger National Park had developed a significant international profile over time and is now the anchor of the wildlife-tourism industry in South Africa.

Scenic beauty and wildlife remain major tourism attractions (ecotourism) for both international and national tourists, who make up $80 \%$ of the tourist numbers in or to South Africa (GCIS 1998; GCIS 1999). However, South Africa is one of many countries or destinations worldwide that offers this type of tourism product. As countries and destinations strive to increase their share of the international and national tourism market, it becomes important to understand why people travel and why they choose a specific destination (Oh, Uysal and Weaver 1995). Therefore, the purpose of this study is to determine the reasons (the travel motives) why tourists visit the Kruger National Park. By determining the motives, according to Saayman (2006), marketing can be undertaken more effectively and specific factors can be taken into account when marketing strategies are being planned.
This article is organised as follows: the literature review follows the introduction, then the method of research, which is followed by the results of the research, after which certain conclusions are drawn and recommendations are made.

\section{LITERATURE REVIEW AND PROBLEM STATEMENT}

In 1994, Fodness (1994) stated that effective tourism marketing is impossible without an understanding of the consumers motivations, or, to put it differently, to know the answer to the question of what motivates people to travel. The aim of marketing, according to Saayman (2006), is the effective and efficient use of resources in the changing environment of today in order to ensure a profit, survival, and growth of the tourism organisation destination. Fodness (1994) adds that further insights into tourists' travel motivation can benefit tourism marketing, specifically with regard to product development, service quality evaluation, image development and promotional activities.

Mill and Morrison (1985) support the notion that motivation plays a very important role in the process of travelling, vacation, and when visiting friends and relatives. Motivation comes into play when a person wants to satisfy a need and must take action to do so. Mill and Morrison (1985) state further that the behaviour of tourists is influenced by a small number of factors, and a person can be motivated by more than one motive at a time. A literature review on travel motivation revealed a wide variety of motivations and a great number of publications, the following of which are merely a few examples:

- Jang and $\mathrm{Wu}$ (2006) studied the travel motivations of Taiwanese seniors

- Oh et al. (1995) investigated Australian tourists' travel motivations

- Tao, Eagles and Smith (2004) looked into motivations of Asian tourists travelling to Taiwan's Taroko National Park

- Awaritefe (2004) looked into tourists' travel motivations to Nigeria

- Fodness (1994) looked into travel motivations for leisure travel 
- Correia, Oom do Valle and Moço (2007) looked into tourists' travel motivations to exotic places

- Uysal et al. (1994) looked into travel motivations of Australian tourists to US national parks and nature areas

- Bansal and Eiselt (2004) looked into tourists' travel motivations to Canadian Maritime Province

- Swanson and Horridge (2006) looked into travel motivations influencing the type of souvenirs tourists purchase

- Kim, Borges and Chon (2006) investigated travel motivations of visitors to festivals

- Backman, Backman, Uysal and Sunshine (1995) examined dimensions of event motivations

- Schneider and Backman (1996) examined the crosscultural equivalence of a motivation scale

- Lee, Lee and Wicks (2004) identified the underlying dimensions of motivations of visitors attending the 2000 World Culture Expo

- Yoon and Uysal (2005) investigated tourists' travel motivations in general

Based on an analysis of the findings of the above authors, it is clear that tourists have different motives for visiting different attractions and/or destinations, as can be seen from Table 1 .

The literature review also clearly revealed that very little research has been done on travel motives to national parks. Studies focusing on the latter are those of Uysal et al. (1994), Tao et al. (2004), and Awaritefe (2004). Uysal et al. (1994) conducted research on Australian tourists visiting national parks and natural areas in the United States. Five factors were identified, namely, "relaxation/hobbies," "novelty," "enhancement of kinship relations," "escape" and "prestige". Tao et al. (2004) focused on Asian tourists visiting Taroko National Park in Taiwan. Two factors have been identified, namely, "learning about nature" and "participating in recreation activities". Awaritefe (2004) conducted research on tourists visiting parks in Nigeria. The most significant motives were self-actualisation, an educational or cultural context, and recreational or leisure pursuits. After the three studies conducted on visitors to national parks as indicated above have been compared, the results are still not comparable. This shows that different visitors to different parks have quite different motives. This could be because of (1) what these parks offer, (2) where they are located, (3) the type of market and (4), the type of activities, to name but a few. Therefore, the lack of research done at national parks in general and the fact that different parks revealed different results was the motivation underlying this research. Added to this is the fact that never before has this type of research been conducted at national parks in South Africa. Uysal et al. (1994) add to this understanding that, in order to market effectively, it is essential to generate more specific knowledge about visitors to parks and natural areas. Oh et al. (1995) conclude that if countries strive to increase their share of visitors, it becomes essential to understand why people travel and why they choose a specific destination.

\section{METHOD OF RESEARCH}

Since the data used in the analysis were gathered by means of consumer-based questionnaires over a period of seven years, namely 2001 to 2007, the methodology used will be discussed under the following headings: (i) the questionnaire, (ii) the samples, and (iii) the method.

\section{The Questionnaire}

The questionnaire used to survey visitors to the Kruger National Park remained similar throughout the period (2001-2007) of data collection and consisted of three sections. In Section A, demographic details were surveyed while section B focused on spending behaviour (marital status, age, province of origin,

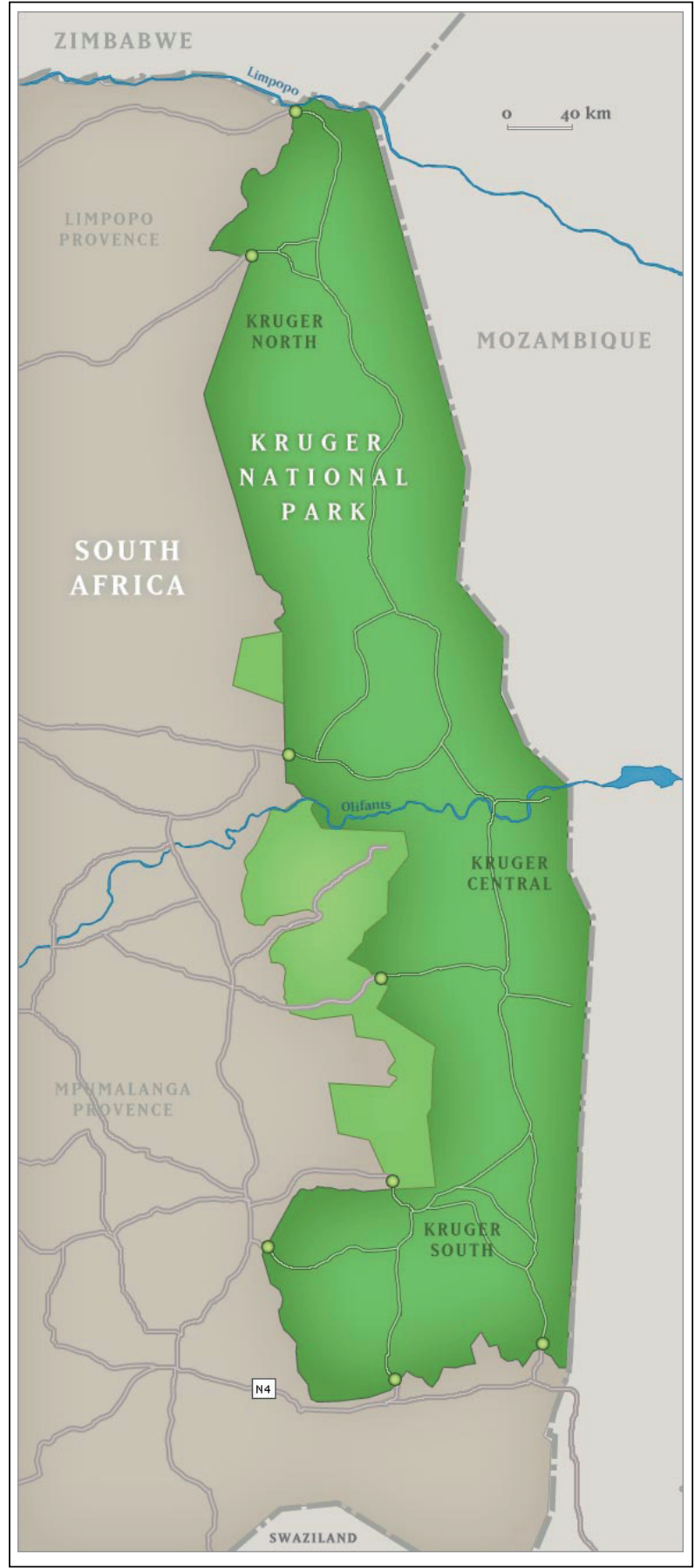

FIGURE 1

Kruger National Park

(Source: African Safari Travel, 2007)

number of persons paid for, frequency of visits, length of stay and amount spent) and motivational factors. The section on travel motivations was based on the work of Crompton (1977) and was adapted for national parks. Section $C$ of the questionnaire consisted of more detailed information about the consumer's general behaviour (type of magazines or newspapers they read and their catering preferences, for example). For the purposes of this article, the information obtained from sections A and B is predominantly used.

\section{The Samples}

Surveys at the Kruger National Park were conducted annually between 2001 and 2005. Since 2006, two surveys were conducted annually, in winter and in summer. In Table 2, the 
TABLE 1

Analysis of research on travel motives

\begin{tabular}{|c|c|}
\hline RESEARCHER/S & TRAVEL MOTIVES \\
\hline $\begin{array}{l}\text { Backman, Backman, } \\
\text { Uysal and Sunshine } \\
\text { (1995) }\end{array}$ & $\begin{array}{l}\text { - Excitement } \\
\text { - External } \\
\text { - Family } \\
\text { - Socialising } \\
\text { - Relaxation }\end{array}$ \\
\hline $\begin{array}{l}\text { Schneider and } \\
\text { Backman (1996) }\end{array}$ & $\begin{array}{l}\text { - Family togetherness } \\
\text { Socialisation } \\
\text { - Social/leisure } \\
\text { Festival attributes } \\
\text { - Escape } \\
\text { - Event excitement }\end{array}$ \\
\hline $\begin{array}{l}\text { Lee, Lee and Wicks } \\
\text { (2004) }\end{array}$ & $\begin{array}{l}\text { - Cultural exploration } \\
\text { - Family togetherness } \\
\text { - Novelty } \\
\text { - Escape } \\
\text { - Event attractions } \\
\text { - Socialisation }\end{array}$ \\
\hline Fodness (1994) & $\begin{array}{l}\text { - Knowledge function } \\
\text { - Utilitarian function (punishment, minimisation) } \\
\text { - Value expressive function (self-esteem) } \\
\text { - Value expressive function (self-enhancement) } \\
\text { - Utilitarian function (reward maximisation) }\end{array}$ \\
\hline Jang and Wu (2006) & $\begin{array}{l}\text { Pull Factors: } \\
\text { - Cleanliness and safety } \\
\text { - Facilities, events and costs } \\
\text { - Natural and historic sites } \\
\text { Push factors: } \\
\text { - Ego-enhancement } \\
\text { - Self-esteem } \\
\text { - Knowledge seeking } \\
\text { - Relaxation } \\
\text { - Socialisation }\end{array}$ \\
\hline Yoon and Uysal (2005) & $\begin{array}{l}\text { - Excitement } \\
\text { - Rnowledge and learning experience } \\
\text { - Achievement } \\
\text { - Family togetherness } \\
\text { - Escape } \\
\text { - Safety } \\
\text { - Fun }\end{array}$ \\
\hline Oh et al. (1995) & $\begin{array}{l}\text { - Safety/comfort seekers } \\
\text { - Culture/history seekers } \\
\text { - Novelty/adventure seekers } \\
\text { - Luxury seekers }\end{array}$ \\
\hline Kim et al. (2006) & $\begin{array}{l}\text { - Family togetherness } \\
\text { Socialisation } \\
\text { - Site attraction } \\
\text { - Festival attraction } \\
\text { - Escape from routine }\end{array}$ \\
\hline $\begin{array}{l}\text { Swanson and Horridge } \\
\text { (2006) }\end{array}$ & $\begin{array}{l}\text { Internal motivators: } \\
\text { - Desire for escape } \\
\text { - Rest } \\
\text { - Relaxation } \\
\text { - Prestige } \\
\text { - Health and fitness } \\
\text { - Social interaction } \\
\text { External motivators: } \\
\text { - Attractiveness of the destination } \\
\text { - Tangible resources (beaches, recreational } \\
\text { activities and cultural attractions) } \\
\text { - Travellers' perceptions and expectations (novelty, } \\
\text { benefit expectations and marketing image) }\end{array}$ \\
\hline $\begin{array}{l}\text { Bansal and Eiselt } \\
(2004)\end{array}$ & $\begin{array}{l}\text { - Climate } \\
\text { - Relaxation } \\
\text { - Adventure } \\
\text { - Personal } \\
\text { - Education } \\
\text { - Sites and festivals }\end{array}$ \\
\hline $\begin{array}{l}\text { Correia, Oom de Valle } \\
\text { and Moço. (2007) }\end{array}$ & $\begin{array}{l}\text { The research revealed three push factors/motives: } \\
\text { - Knowledge } \\
\text { - Leisure } \\
\text { The pocialisation } \\
\text { - Factors that were revealed were: } \\
\text { - Core attractions } \\
\text { - Landscape features }\end{array}$ \\
\hline $\begin{array}{l}\text { Loker and Perdue } \\
\text { (1992) }\end{array}$ & $\begin{array}{l}\text { - Excitement and escape } \\
\text { - Adrenalin, excitement seeking } \\
\text { - Namily and friends-oriented } \\
\text { surralist (those who enjoyed nature } \\
\text { - Escape (those who valued the escape by itself) }\end{array}$ \\
\hline
\end{tabular}

TABLE 1 (CONT...)

\begin{tabular}{|c|c|}
\hline RESEARCHER/S & TRAVEL MOTIVES \\
\hline $\begin{array}{l}\text { Goeldner, Ritchie and } \\
\text { McIntosh (2000) }\end{array}$ & $\begin{array}{l}\text { - Spirituality } \\
\text { - Social status } \\
\text { - Escape } \\
\text { - Cultural enrichment }\end{array}$ \\
\hline Crompton (1977) & $\begin{array}{l}\text { Identified seven socio-psychological motives for } \\
\text { travelling: } \\
\text { - Escaping from the everyday environment } \\
\text { - Discovering and evaluating of oneself } \\
\text { - Recreation and travelling } \\
\text { - Status } \\
\text { - Regression } \\
\text { - Strengthening of family ties } \\
\text { - Facilitation of social interaction }\end{array}$ \\
\hline $\begin{array}{l}\text { Weaver and } \\
\text { Oppermann (2000) }\end{array}$ & $\begin{array}{l}\text { Identified three categories: } \\
\text { - Leisure } \\
\text { - Visiting friends and relatives } \\
\text { They can be subdivided into the following four } \\
\text { categories: } \\
\text { - Relaxation and recreation } \\
\text { - Sport and health } \\
\text { - Religion } \\
\text { - Education }\end{array}$ \\
\hline
\end{tabular}

sample sizes and the different camps where the surveys were conducted are given, and it is evident that the sample size has grown significantly over the past years. All visitors to the camp received a questionnaire that they completed in their own time. Field workers collected the questionnaires again during the evenings and early mornings.

Note that the definition of a tourist is applied for the purpose of this research and therefore only overnight visitors have been considered in the analyses. A total of 2899 questionnaires were administrated and, according to Saayman and Fouché (2007), the profile of visitors has remained similar since 2001. Hence it is believed that the sampling is representative of the population.

\section{The method}

Microsoft Excel was used for data capturing and basic data analysis. The factor analysis was conducted by means of SPSS (2006) and Oblique Promax with a Rotation Oblimin method was used. To explain the variance-covariance structure of a set of variables through a few linear combinations of these variables, a principal component analysis can be applied. The aim of such an analysis is to (i) reduce the data and (ii) to assist in the interpretation of the data. Although $p$ components are required to explain the total variability in the system, much of this variability can normally be accounted for by a small number, $k$, of principal components. There is almost as much information in $k$ components as there is in the initial $p$ variables. The $k$ components can thus replace the $p$ variables, thereby reducing the data set. The analysis often reveals relationships that were not previously suspected and thereby allows interpretations that would not ordinarily result (Johnson \& Wichern, 2002: 426).

Factor analysis extends a principal component analysis, since both can be viewed as attempts to approximate the covariance matrix. However, the approximation based on the factor analysis model is much more elaborate than that of a principal component analysis. Although factor analysis has its origin in the measurement of intelligence, it can be applied to most disciplines with success. The purpose of a factor analysis is to describe the covariance relationships among many variables in terms of a few underlying, but unobservable, random quantities called factors. The factor model can be motivated by the following argument: Suppose that variables can be grouped according to their correlations. That is, all variables in a particular group are highly correlated among themselves, but small correlations with variables in a different group. If this is 
TABLE 2

Total number of questionnaires completed -2001 to 2007

\begin{tabular}{|c|c|c|c|c|c|c|c|c|}
\hline YEAR & 2001 & 2002 & 2003 & 2004 & 2005 & 2006 & 2006 & 2007 \\
\hline Survey month & May & July & December & December & December & July & November & June \\
\hline \# of questionnaires & 220 & 323 & 246 & 400 & 450 & 476 & 171 & 613 \\
\hline Camps & $\begin{array}{l}78 \text { Berg en Dal } \\
68 \text { Satara } \\
40 \text { Olifants } \\
34 \text { Shingwedzi }\end{array}$ & $\begin{array}{l}62 \text { Berg en Dal } \\
87 \text { Satara } \\
93 \text { Olifants } \\
81 \text { Shingwedzi }\end{array}$ & $\begin{array}{l}20 \text { Berg en Dal } \\
75 \text { Satara } \\
21 \text { Olifants } \\
66 \text { Lower Sabie } \\
64 \text { Skukuza }\end{array}$ & $\begin{array}{l}70 \text { Berg en Dal } \\
84 \text { Satara } \\
39 \text { Olifants } \\
72 \text { Lower Sabie } \\
135 \text { Skukuza }\end{array}$ & $\begin{array}{l}57 \text { Berg en Dal } \\
128 \text { Satara } \\
79 \text { Letaba } \\
63 \text { Lower Sabie } \\
128 \text { Skukuza }\end{array}$ & $\begin{array}{l}19 \text { Malelane } \\
74 \text { Pretoriuskop } \\
249 \text { Skukuza } \\
49 \text { Olifants } \\
85 \text { Letaba }\end{array}$ & $\begin{array}{l}36 \text { Letaba } \\
55 \text { Skukuza } \\
80 \text { Satara }\end{array}$ & $\begin{array}{l}161 \text { Berg en Dal } \\
173 \text { Satara } \\
191 \text { Skukuza } \\
88 \text { Letaba }\end{array}$ \\
\hline
\end{tabular}

TABLE 3

Visitors profile: Kruger National Park 2001-2007

\begin{tabular}{|c|c|}
\hline CATEGORY & PROFILE \\
\hline Home language & Afrikaans $(70 \%)$ \\
\hline Age & $35-49$ years of age (Average:44,5) \\
\hline Marital status & Married (84\%) \\
\hline Province of residence & $\begin{array}{l}\text { Gauteng and Western Cape predominantly } \\
\text { during winter months } \\
\text { Mpumalanga and Gauteng during summer } \\
\text { months }\end{array}$ \\
\hline Level of education & Diploma/Degree $(80 \%)$ \\
\hline Number of people paid for & $3-4$ people \\
\hline Mode of transport & Sedan and $4 \times 4$ vehicle \\
\hline $\begin{array}{l}\text { Number of visits to national } \\
\text { parks over } 3 \text { years }\end{array}$ & 6 times ( 2 per year) \\
\hline Length of stay & $\begin{array}{l}4-14 \text { days during winter and 2-7 days during } \\
\text { summer }\end{array}$ \\
\hline Preference of the park & Wildlife \\
\hline Reasons for visiting the park & To relax \\
\hline Expenditure & $\begin{array}{l}\text { R6 } 000 \text { per trip (winter months) } \\
\text { R5 } 000 \text { per trip (summer months) }\end{array}$ \\
\hline Visitor references & Self-catering \\
\hline Preferred newspaper & Rapport and Beeld \\
\hline Preferred magazines & Weg, Huisgenoot/You, Getaway/Wegbreek \\
\hline Preferred radio stations & Jacaranda and Highveld Stereo \\
\hline Preferred TV programmes & Sport, nature and news \\
\hline Heard about the park & Word-of-mouth \\
\hline Preferred accommodation & Chalets \\
\hline
\end{tabular}

the case, it is conceivable that each group of variables represents a single underlying factor that is responsible for the observed correlations. It is this type of structure that a factor analysis seeks to confirm (Johnson \& Wichern 2002).

\section{RESULTS}

The results will be discussed in two sections. Firstly, an overview of the profile for visitors to the Kruger National Park will be given, and, secondly, the results of the factor analysis (visitor motives) will be discussed.

Four surveys were conducted during the summer season (November/December) and four during the winter season (May/July). Due to this, there were minor differences between the summer and winter profile of visitors such as province of origin (see Table 3) and length of stay - tourists tend to stay longer during winter season, which leads to increased spending during the winter seasons.

Based on the results captured in Table 3, tourists visit national parks at least twice a year. These tourists are loyal to this particular park and they enjoy the wildlife that the park offers. In addition, they want to relax. These tourists are predominantly Afrikaans speaking (one of South Africa's eleven official languages), and are approximately 45 years old, coming mainly from Gauteng and the Western Cape Province. Visitors to this park are well educated and they stay for an average of one week. The descriptive results showed that "to relax" was regarded as the most important reason for visiting the park.
The next section will deal with the motives for travelling as indicated by the factor analysis.

The factor analysis (Pattern Matrix) identified six factors. Based on the items included in the identified factors, these factors can be named accordingly from Table 4: nature, activities, attractions, nostalgia, novelty, and escape from routine.

- Factor 1: Nature

Nature included aspects such as "to see endangered species," "to see animals," "to see plants," "for educational reasons," "to take photos of animals" and "to take photos of plants". This factor is confirmed by Oh et al. (1995) as well as Swanson and Horridge (2006) as a motive for travel. It should be noted, however, that none of those studies were conducted at national parks. Nature as a factor has a mean value of 3.0062, which is the third highest of the six factors.

- Factor 2: Activities

Activities include sub-categories such as "to attend conferences," "to attend events" and "hiking". Oh et al. (1995) also found that activities such as nightlife, exotic atmospheres, and amusement or theme parks play an important role in the travel motivations of tourists. Of the six factors, this one scored the lowest mean value of 1.5392 .

- Factor 3: Attractions

Attractions include "accommodation," "brand of the park," "climate of location" and "grew up with the park". Kim et al. (2006) also indicated that "attractions" is an important travel motivator. This factor has a mean value of 2.8072 .

\section{- Factor 4: Nostalgia}

Nostalgia consists of "family time", "park is visited from childhood days", "to experience wildlife", "family time", and "different species". This aspect achieved the second highest mean value of 3.4352. None of the other research projects consulted during the literature review identified this as a motive for travelling.

- Factor 5: Novelty

Novelty consists of "explore new destinations" and "socialising with friends". The same travel motive was identified by Uysal et al. (1994) for Australian tourists visiting national parks in the United States of America. This motive has also been identified in research by $\mathrm{Oh}$ et al. (1995) and Lee et al. (2004) and has a mean value of 2.7724 .

- Factor 6: Escape from routine

Factor 6 consists of "routine vacation" and "to relax". Uysal et al. (1994) and Kim et al. (2006) found that "escape from daily routine" was an important motive for tourists to travel. Kim et al. (2006) further indicated that "escape" includes aspects such as "to get away from demands of life" and "daily routine". Swanson and Horridge (2006) also identified "escape" as an important travel motivator, and included aspects such as "seeing spectacular scenery," 
TABLE 4

Pattern matrix

\begin{tabular}{|c|c|c|c|c|c|c|}
\hline \multirow[b]{2}{*}{ TRAVEL REASONS } & \multicolumn{6}{|c|}{ COMPONENT } \\
\hline & NATURE & ACTIVITIES & ATTRACTIONS & NOSTALGIA & NOVELTY & ESCAPE \\
\hline Mean values & 3.0062 & 1.5392 & 2.8072 & 3.4352 & 2.7724 & 4.2133 \\
\hline $\begin{array}{l}\text { To see endangered species } \\
\text { To see animals } \\
\text { To see plants } \\
\text { For educational reasons } \\
\text { To take photos of animals } \\
\text { To take photos of plants }\end{array}$ & $\begin{array}{l}.854 \\
.809 \\
.741 \\
.671 \\
.560 \\
.498\end{array}$ & & & & & \\
\hline $\begin{array}{l}\text { To attend conferences } \\
\text { To attend events } \\
\text { Hiking }\end{array}$ & & $\begin{array}{l}.856 \\
.780 \\
.763\end{array}$ & & & & \\
\hline $\begin{array}{l}\text { Accommodation } \\
\text { Brand of the park } \\
\text { Climate of location } \\
\text { Grew up with the park }\end{array}$ & & & $\begin{array}{l}.805 \\
.637 \\
.629 \\
.482\end{array}$ & & & \\
\hline $\begin{array}{l}\text { Park is visited since childhood } \\
\text { To experience wildlife } \\
\text { Family time } \\
\text { Different species }\end{array}$ & & & & $\begin{array}{l}-.780 \\
-.695 \\
-.653 \\
-.624\end{array}$ & & \\
\hline $\begin{array}{l}\text { Explore new destinations } \\
\text { Socialising with friends }\end{array}$ & & & & & $\begin{array}{l}.794 \\
.555\end{array}$ & \\
\hline $\begin{array}{l}\text { Routine vacation } \\
\text { Relaxation }\end{array}$ & & & & & & $\begin{array}{l}.825 \\
.787\end{array}$ \\
\hline
\end{tabular}

TABLE 5

Component Correlation Matrix

\begin{tabular}{|c|c|c|c|c|c|c|}
\hline COMPONENT & NATURE & ACTIVITIES & ATTRACTIONS & NOSTALGIA & NOVELTY & ESCAPE \\
\hline Nature & 1.000 & .206 & .228 & -.219 & .115 & .110 \\
\hline Activities & .206 & 1.000 & .227 & -.013 & .072 & -.096 \\
\hline Attractions & .228 & .227 & 1.000 & -.194 & .048 & .171 \\
\hline Nostalgia & -.219 & -.013 & -.194 & 1.000 & -.141 & -.094 \\
\hline Novelty & .115 & .072 & .048 & -.141 & 1.000 & -.030 \\
\hline Escape & .110 & -.096 & .171 & -.094 & -.030 & 1.000 \\
\hline
\end{tabular}

"visiting places I've never seen before" and "visiting exiting places". This factor scored the highest mean value of the six factors, namely 4.2133, and is the most common motive for travel if one compares the various research projects in Table 1.

Based on the results of the component correlation matrix as captured in Table 5, the low correlation between the different factors shows that the factors can be clearly distinguished. The motives of tourists visiting the Kruger National Park are thus very specific and well defined. The table indicates that tourists visiting the park to experience nature have similar motives to those of tourists visiting the park for activities or to escape from routine, for example.

Based on this research, the next section will discuss the findings and conclusions.

\section{FINDINGS AND CONCLUSIONS}

The aim of this article was to determine the travel motives of tourists visiting the Kruger National Park in South Africa. This was the first time that this type of research was conducted in a national park in South Africa.

The results of the survey revealed six travel motives, namely nature, activities, attractions, nostalgia, novelty, and escape. From the results of the literature review, it became clear that these findings support the notion that different attractions and destinations feed different motives to travel. Therefore, it was expected that motives for visiting the Kruger National Park would also be different or at least similar to some of the studies conducted at other national parks. Research by Uysal et al. (1994),
Kim et al. (2006), Swanson and Horridge (2006) and Oh et al. (1995) confirmed some of the motives in their research, although the similarities are not noticeably significant. Compared to research by Uysal et al. (1994) where the latter had five motives, only two, namely novelty and escape, were similar. None of the motives from the research by Tao et al. (2004) or Awaritefe (2004) were similar, although those particular studies were also conducted in national parks. The motives that were comparable with other research in other fields of tourism remain novelty and escape. It therefore seems that people travel to escape from their everyday routine as well as to experience something new. Research in the Kruger National Park confirmed that the motives with the highest mean value were to escape, followed by nostalgia and nature.

The latter is very important information for marketers of national parks, since the marketing campaign could be based on these findings. Therefore, the concept of a "place to escape" can be used successfully, as this is a major motive. Coupled to that is the aspect of nostalgia, and then the aspect of nature. In the past, marketers focused primarily on the wildlife that the Kruger National Park has to offer, especially the Big 5. Although this focus was successful, very little was done with regard to the escape motive. Combining the nature and escape motives, for example "Kruger National Park, a place to escape while enjoying the Big 5 ", could add value to the marketing campaign. It is interesting to note that nostalgia as a motive has a higher rating than nature in the case of Kruger National Park. This is the first time that this motive was identified in research on travel motivations. A possible reason for this could be that most of the tourists visit this park regularly and could be regarded as brand loyal. They therefore become "attached" to the park. Another possible reason could be that most of these brand-loyal tourists grew up with the park. 
The contribution of this research lies in the confirmation of "escape" as the most important motive for visiting the Kruger National Park, as well as the role that nostalgia plays. Added to this, the study conducted by Uysal et al. (1994) in national parks in the USA showed a slight similarity in terms of novelty and escape as travel motives. Similar research in other national parks, however, showed no similarities. It would, therefore, be interesting to establish the motives for travelling to other national parks in South Africa. Added to this could be the desire to classify the distinguishing motives between national and international tourists visiting national parks, and particularly the Kruger National Park. However, it could be anticipated that nostalgia may not be such an important role motivation to the international tourist.

\section{ACKNOWLEDGEMENTS}

The authors would like to thank SANParks for financial assistance (especially Mr Glenn Phillips). We also would like to thank all the referees for their input in improving the document.

\section{REFERENCES}

African safari travel. 2007. Kruger National Park map. Available at:www.go2africa.com/south-africa/kruger-national-Park/ map. [Accessed 3 December 2007].

Awaritefe, O.D. 2004. Motivation and other considerations in tourist destination choice: a case study of Nigeria. Tourism Geographies, 6(3): 303-330.

Bansal, H. \& Eiselt, H.A. 2004. Exploratory research of tourists' motivations and planning. Tourism Management, 25: 387396

Backman, K.F., Backman, S.J., Uysal, M. \& Sunshine, K.M. 1995. Event tourism: An examination of motivations and activities. Festival Management and Event Tourism, 3(1): 15-24.

Correia, A., Oom Do Valle, P. \& Moço, C. 2007. Why people travel to exotic places. International Journal of Culture, Tourism and Hospitality Research, 1(1): 45-61.

Crompton, J.L. 1977. Motives for pleasure vacation. Annals of Tourism Research, 1(4): 408-424.

Eagles, P.F.J. \& McCool, S.F. 2002. Tourism in national parks and protected areas: planning and management. Wallingford: CABI Publishing.

Fodness, D. 1994. Measuring tourist motivation. Annals of Tourism Research, 21(3): 555-581.

GCIS (Government Communication and Information System). 1998. South Africa Official Yearbook, Cape Town: Rustica.

GCIS (Government Communication and Information System). 1999. South Africa Official Yearbook, Cape Town: Rustica

Goeldner, C.R., Ritchie, J.R. \& McIntosh, R.W. 2000. Tourism principles: practices and philosophies. 8th ed. New York: Wiley.
Jang, S. \& Wu, C.E. 2006. Seniors' travel motivations and the influential factors: an examination of Taiwanese seniors. Tourism Management, 27: 306-316.

Johnson, R.A. \& Wichern, D.W. 2002. Applied Multivariate Statistical Analysis, 5th ed. New Jersey: Prentice Hall.

Joubert, S.C.J. 2007. The history on the development of the Sabie and Shingwedzi Reserves and the Kruger National Park, 1898 to 1946. Available at: www.sanparks.org. [Accessed 12 August 2007].

Kim, H., Borges, M.C. \& Chon, J. 2006. Impacts of environmental values on tourism motivations: the case of FICA, Brazil. Tourism Management, 27: 957-967.

Lee, C.K., Lee, Y.K. \& Wicks, B.E. 2004. Segmentation of festival motivation by nationality and satisfaction. Tourism Management, 25: 61-70.

Loker, L. \& Perdue, R. 1992. A benefit segmentation of a nonresident summer travel market. Journal of Travel Research, 31(1): 31-35.

Mill, R.C. \& Morrison, A.M. 1985. The tourism system: an introductory text. Englewood Cliffs: Prentice Hall.

Oh, H.C., Uysal, M., Weaver, P.A. 1995. Product bundles and market segmentation based on travel motivations: a canonical correlation approach. Hospitality Management, 14(2): 123-137.

Pienaar, U De V. 2007. Neem uit die Verlede. Available at: www. sanparks.org. [Accessed 12 August 2007].

Saayman, M. 2006. Marketing tourism, in Products $\mathcal{E}$ destinations: Getting back to basics. 2nd ed. Potchefstroom: Leisure Consultants and publications, p. 234

Saayman, M. \& Saayman, A. 2006. Estimating the economic contribution of visitor spending in the Kruger National Park to the regional economy. Journal of Sustainable Tourism, 14(1): 67-81.

Saayman, M. \& Fouché, M. 2007. Executive summary of research profiles for selected National Parks in South Africa. Potchefstroom: Institute for Tourism and Leisure Studies.

Schneider, I.E. \& Backman, S.J. 1996. Cross-cultural equivalence of festival motivations: A study in Jordan. Festival Management and Event Tourism, 4(3/4): 139-144.

SPSS Inc. 2006. SPSS $® 15.0$ for Windows, Release 15.0.0, Copyright $\odot$ by SPSS Inc. Chicago: Illinois.

Swanson, K.K. \& Horridge, P.E. 2006. Travel motivations as souvenir purchase indicators. Tourism Management, 27: 671683.

Toa , C.H., Eagles, P.F.J. \& Smith, S.L.J. 2004. Profiling Taiwanese ecotourists using a self-definition approach. Journal of Sustainable Tourism, 12(2): 149-168.

Uysal, M., Mcdonald, C.D. \& Martin, B.S. 1994. Australian visitors to US national parks and natural areas. International Journal of Contemporary Hospitality Management, 6(3): 18-24.

Weaver, D.B. \& Oppermann, M. 2000. Tourism Management. Brisbane: Wiley Australia.

Yoon, Y. \& Uysal, M. 2005. An examination of the effects of motivation and satisfaction on destination loyalty: A structural model. Tourism Management, 26: 45-56. 